\title{
Innovation and the Public Service: Facilitating Inclusive Industrial and Social Development
}

\author{
Working Paper
}

The final, open access version of this article is available here:

Plantinga, P. (2022). Innovation and the public service: Facilitating inclusive industrial and social development. In C. Hongoro, C. Adonis, \& K. Sobane (Eds.), Innovation for inclusive development and transformation in South Africa (pp. 85-109). Cape Town: AOSIS.

https://books.aosis.co.za/index.php/ob/catalog/book/384

Paul Plantinga

Human Sciences Research Council, South Africa

pplantinga@hsrc.ac.za

\section{Abstract}

A growing number of public servants are involved in activities aimed at supporting industrial and social innovation in their regions, whether by firms, academia, civil society or community-based organisations. But what capabilities and legitimacy do government officials and their agencies have to engage meaningfully with these innovation actors? Much of the current research highlights significant friction between the open, agile behaviour needed to support innovation and the inertia of established bureaucratic procedures and attitudes. A common response is that the public sector needs to be 'de-bureaucratised'. Through a case study of South Africa, this chapter seeks to provide a more nuanced picture of the capacities and routines that are important for enabling innovation. This is done by highlighting (1) the significant diversity of public organisations and officials influencing industrial and social innovation; (2) the reasons why certain procedures and practices are in place; and (3) potential adjustments through which innovation support can be improved, including how it can better serve inclusive development goals. This analysis is an initial attempt to profile the distinctive characteristics of innovation enablers in the public sector, and provides a framework for identifying routines through which innovation and inclusive development outcomes may be achieved.

\section{Introduction}

Public servants are concerned with innovation from two perspectives. First, they are looking to promote innovation inside their own agencies or departments, to improve service delivery and reduce costs. This is usually termed 'public sector innovation' (PSI). Second, they aim to facilitate and support innovation in the economy and society broadly; by funding or incentivising research and development (R\&D) in industry, by providing training and market intelligence services, and by building links between knowledge creators and users. This chapter focuses on the latter role, and the associated routines, capacities and 
legitimacies that are needed to effectively support external innovation activity - whilst also recognising that there are significant dependencies between the two perspectives and associated capabilities.

With renewed interest in the role of a developmental and now 'entrepreneurial' state in supporting innovation, there is growing demand for public officials to adopt new ways of working to realise innovation goals; from defining and coordinating multi-sector innovation 'missions', to implementing open and experimental policy practices, and creating digital platforms to facilitate knowledge exchange (The Presidency 2019; Mazzucato 2013; Kankanhalli et al. 2017; OECD 2019; Daniels et al. 2020).

Research from South Africa has highlighted similar trends and associated changes to what is needed from public officials: It is now widely recognised that successful industrial and scientific innovation depends on a mix of local and global knowledge and resources, from different sectors (Reddy 2011). At the same time, there is more recognition of the importance of informal innovation activity taking place at the periphery of economies, and which is central to people's survival and development strategies (Kraemer-Mbula et al. 2019). As a result, across all spheres of government there is an expectation that public officials become innovation brokers (Jacobs et al. 2019: 896). This includes stimulating 'a multi-spatial and open innovation system which fosters strong linkages with national and international agencies, institutions and actors to access to knowledge, financial resources, and global markets to stimulate learning, collaboration and innovation' (Ndabeni et al. 2016: 308).

However, these same studies acknowledge that there are fundamental challenges with how the public sector operates, which affects its ability to build linkages and stimulate learning across industries and society. This is not unique to South Africa. Much of the inability of the state to adopt emerging practices and engage with other sectors to facilitate innovation is put down to 'flaws' inherent to the state's bureaucratic machinery, such as opaqueness and rigid processes (OECD 2019). A popular response has been to establish relatively autonomous innovation agencies or programmes which have some freedom to define their own culture, brand and (open and agile) processes (Breznitz et al. 2018). The peripheral status of these agencies is seen as key 'to reduce the likelihood of political interference and to allow space and to create organizational need for policy experimentation (and innovation)' (Karo \& Kattel 2016a: 8).

However, in South Africa, the reality for autonomous agencies and hubs is often quite different from what was anticipated when they were established. Typically, these entities and instruments continue to be resourced via public servants located in traditional government structures. In addition, most public-financed agencies and hubs continue to operate within the same or similar legal frameworks as their government funders, reporting to the same political principals (Masilela 2008; Kaplan 2021). As a result, these entities are not able to operate with the freedom that many external stakeholders expect, and emerging entrepreneurs regularly express their frustration when engaging with public officials involved in innovation and enterprise development (Reyneke 2020). All of this is seen as typical of an 'ingrained parastatal bureaucracy' (Sibanda 2020: 266). 
For a number of innovation policy researchers and commentators, getting out of this bureaucratic trap is seen to depend on a more wholesale change of mindset and culture across the public sector, highlighting the dependence on PSI mentioned earlier. There are many ongoing, internally-oriented programmes which aim to mainstream innovation within public entities. Such inside-out reform is expected to improve service delivery effectiveness and efficiency, whilst enhancing public capacity for facilitating external industrial and social innovation (Petersen \& Kruss 2020). It is hard to disagree with calls for increased creativity and innovation to address persistent service delivery and socio-economic challenges.

However, to better understand how this capability can be developed, it is important to be conscious of the diverse organisations, individuals and values at play in the public sector environment (Karo \& Kattel 2016a; Hood 1991).

Systems of innovation scholars have long highlighted the need to recognise organisational diversity and how this varies across contexts and time. A variety of public sector organisations support the practical realisation of various (formally and informally defined) institutional rules, norms and resourcing activities. Different enabling functions include, amongst others, networking, financing and incubation (Edquist \& Johnson 1997; Edquist \& Hommen 2008). As a practical tool, the OECD popularised the use of 'institutional mappings', including in South Africa (OECD 2007; Kruss \& Lorentzen 2011), to identify key (mainly public sector) entities and functions involved in the formulation of policy, financing and funding of R\&D and those that play a bridging role - such as for technology transfer. The OECD noted the complex, variable nature of this support system across countries (1999: 30-41).

So, rather than simply pushing for the uniform adoption of innovation practices and administrative values that have had success in certain organisations and regions - such as openness, participation (Drechshler \& Karo 2017) or a business mindset (Chipkin \& Lipietz 2012) - we need to develop a more nuanced perspective of the different roles public servants and public sector organisations may fulfil within the institutional milieu at this point in time. This includes understanding which public sector actors are and could be participating in innovation activities, especially from an inclusion perspective (Daniels et al. 2017: 523), and what distinctive capacities and legitimacy are required to do so effectively.

\section{South Africa case study}

At this point in time South Africa presents an interesting opportunity to explore these issues, partly because a number of new public sector entities are being encouraged to support innovation activity, such as municipalities through their Local Economic Development (LED) plans, but also because the recent White Paper on Science, Technology and Innovation ('STI White Paper') (DSI 2019) has outlined a significant shift towards a more 'inclusive' approach to innovation, which draws on various open principles (Plantinga \& Adams 2020; Plantinga \& Adams 2021).

Whilst much has been written about formal, mostly national STI institutional arrangements; there has been more limited discussion about South Africa's distinctive organisational (and individual) morphology and diversity - with associated values, legitimacies and capacities that enables or inhibits innovation, and how these relate to the broader state priority of 
inclusive development. To address this gap, three questions will be addressed in the following sections.

First, from empirical research and conceptual debate in other regions, how do public entities involved in innovation leverage their distinctive organisational routines, legitimacy and capacity to enable innovation activities; especially in relation to achieving inclusive development as a broader outcome? Second, what has been the policy and programme approach of public entities in South Africa in relation to supporting both firm-level and community-based innovation, and in what way have they pursued inclusive development outcomes? Through a detailed description of the different approaches that public sector organisations, and relevant sub-units, have adopted (and modified or discarded), we are able to better understand why certain forms are in place. The description is based on a content analysis of information contained in policy and programme texts, as well as in relevant media and social media discourse. Finally, by drawing on the theoretical frame developed in the first section, the various South African entities are mapped according to their main organisation types, associated routines and capacities, and inclusion approaches. This analysis is an initial attempt to describe the distinctive characteristics of public sector entities and provides a framework to start identifying possible adjustments to routines that could enhance an organisation or division's role as an innovation enabler.

\section{Mapping organisational diversity}

To develop a rich picture of the types of organisations and practices involved in innovation, the case study draws on a framework used by Karo and Kattel (2016a; 2016b; 2015) to explore the organisational routines of different public entities as they relate to innovation activities. In these papers, the authors adapt Mintzberg's organisational configurations (1989: 110) and Wu et al.'s policy capacities (2015) as a lens to demonstrate how the interaction of a 'variety of organizations with different routines and capacities' (2016: 2) are responsible for realising effective innovation policies in different regions.

For each country, the authors describe how innovation-enabling public sector entities typically fit with five core types, characterised by certain political, policy and administrative capacities, which are realised through the routinisation of certain management activities (See Annexure A for a table summarising the organisation types, routines and capacities). The key management routines are organisational (how core tasks are organised), strategic (how planning and management is performed), personnel (how staff recruitment, reward and learning takes place), financial (how resources are allocated, used and audited), coordination (how internal and external interactions are organised) and research (how new ideas are identified and adopted).

As an example case study, Karo and Kattel describe how the Defense Advanced Research Projects Agency (DARPA) in the USA follows an entrepreneurial managerial approach, which is anchored by a human resources routine based on the recruitment of short-term expertson-loan to work on projects. Program managers are assessed through personal feedback and peer pressure, rather than formal performance management and incentives (2016a). 
Of course, these ideal types are mainly for analytical purposes, and we should expect that there will be mixtures of routines within organisations and variations in time and place. Given South Africa's increasing emphasis on inclusive development as innovation outcome, this chapter seeks to be explicit about governance actions as they relate to inclusive growth and development (OECD 2017; Foster \& Heeks 2015). In addition, the case study considers the growing role of technology in the 'evolution of innovation bureaucracies' (Karo \& Kattel 2016a: 27), especially as public officials look to use digital technologies to facilitate inclusive innovation interactions.

\section{Changing legitimacy and routines}

In innovation policy, the public sector's legitimacy, access to resources and governance approach evolves in line with what countries and regions expect of it, which is tied to underlying rationales related to how innovation takes place in the economy and society (Laranja et al. 2008). An influential rationale is that the public good characteristics of technology information, such as low excludability, disincentivise firm investment in innovation. Under this rationale, policies tend to focus on the protection of intellectual property rights. Public officials, therefore, are mainly expected to support the administration of those rights, which is typical of a traditional professional-bureaucratic function implemented by a government patent office. In recent decades, an innovation 'system' rationale has emphasised the importance of linkages between innovation actors for knowledge accumulation. Under this rationale, public officials are expected to facilitate system-enabling activities such as forums and shared working spaces.

The public innovation agency has emerged as a key enabler of national and regional innovation systems. Innovation agencies are relatively independent entities with flexible organisational and personnel management routines, which allows them to mediate the diverse values and working cultures of government policy and firm-level practice. Breznitz et al. (2018) argue that the design of innovation agencies - including insulation from or embeddedness in political and industrial networks - depends on the type of innovation or mission it aims to pursue. For example, Denmark's government-approved Research and Technology Organisation (GTS institutes) derive close to $90 \%$ of their revenue by working with private sector clients to solve technological challenges, and is therefore deeply embedded in local industrial and small and medium-sized enterprise (SME) networks, working on more incremental innovations. In contrast, larger, state-led agencies in Singapore and Chile have used significant public-funded budgets to support the technological upgrading of strategic industries.

Increasingly, systems thinking has taken a regional turn, providing subnational officials with more legitimacy and resources for driving innovation activity. Similarly, there has been a shift to smart specialisation as a more sector-focused approach to innovation activation. In this case, sub-sector agencies have narrowly defined capacities and legitimacy, often drawing on 'meso-level' policies, networks and labour and industry associations (Cunningham 2012; Karo \& Kattel 2015: 183).

As rationales and associated policy approaches change, public officials need to develop new capacities and routines. For example, if a region is looking to move towards using demand- 
side policies, such as procurement of innovation, there will be a need to develop new policy and administrative routines. This may be done through training and pilot exercises to "build analytical competencies for understanding what types of instruments (procurement vs. standards) may work given the [research, development, and innovation (RDI)] characteristics in specific regions or economies' (Karo \& Kattel 2015: 183).

Certain public entities and associated rationales have a particularly strong influence over external innovation activity. For example, universities and research councils or agencies have been central to the development of scientific skills and in contract research relationships with firms and state-owned enterprises (SOEs) (Kruss 2012). In recent years, there have been significant shifts at the public research-industry interface. As a result, entrepreneurship has become an influential agenda in many university and research council environments, encouraged by the passing of legislation such as the Bayh-Dole Act in the USA. This has led to an expansion in licensing activity and an increased number, but also evolution in the role of technology transfer offices (TTOs) - including working with or establishing business incubators (Rothaermel et al. 2007). These entities typically have more flexible financial routines than the host university, for establishing new ventures and equity investing. Similarly, whilst large industry and SOEs continue to be seen as critical to the development of new industries and fast-tracking industrialisation (Tonurist \& Karo 2016: 630) - which establishes them politically and financially as a key enabler of innovation in certain sectors - start-ups and small business development have become integral to regional and national innovation strategies. These shifts in orientation have led to a proliferation of private and public incubators, co-working spaces and technology hubs, which provide core administrative support for a pipeline of emerging entrepreneurs. It has also led to the emergence of more demand-led programmes, such as the Small Business Innovation Research (SBIR) initiative in the USA (OECD 2010), which have been relatively successful in helping government entities to articulate needs and develop innovation partnerships with small enterprises. These types of programmes require stronger professional, consulting capacities and coordinating routines to match innovation creators with users.

\section{Inclusive development as priority}

The shift into entrepreneurship is linked to a broader reorientation away from high-tech and large-firm innovation. This has been driven by a growing inequality and skills gap as naturalresource abundant countries struggle to transition into value-adding manufacturing activities or enable wider participation in the services sector (Bhorat et al. 2020), and concern about the potential harm to people and the environment that has and will be caused by emerging technologies (Schillo \& Robinson 2017). At the same time there is increasing recognition of the role that more informal, local, co-creation and user-oriented innovation plays in developing countries in particular (Ndabeni et al. 2016; Senyolo et al. 2018; Hart et al. 2020; Jacobs et al. 2019; Kraemer-Mbula et al. 2019).

In response, a substantial field of practice and scholarly work has developed around, amongst others, social (Mulgan 2006), inclusive (OECD 2017), responsible (Schillo \& Robinson 2017), sustainable or transformative (Daniels et al. 2020) and grassroots innovation (Gupta 2006). Whilst this chapter focuses on innovation for inclusive development (IID), the conversations in other areas are critical for understanding policy 
linkages and opportunities that public sector actors are seeking to pursue. For example, for some universities, responsible research and innovation (RRI) is seen as a potential source of competitive advantage (Owen et al. 2020).

When looking at the state role in relation to IID, an OECD report on innovation for inclusive growth emphasises the coupling of policies aimed at social, industrial and territorial inclusiveness (2017: 162), highlighting the need for public officials to have a systemic view on innovation activities as well as coordinating capacities (Petersen \& Kruss 2019). The OECD report also identifies a set of 'expertise' that needs to be built amongst public sector officials and consultants deploying the programmes, such as: creating expert teams to assist regional governments design programmes and proposals for funding by the national government, conducting more targeted recruitment processes that ensure candidates will be able to deal with expected challenges, and enhancing the business skills of those involved in social entrepreneurship work (2017: 198-199). Foster and Heeks (2015) suggest that the starting point for IID policy implementation is for policy actors to adopt a new worldview oriented to the inclusion of marginalised groups, from which specific policy governance actions may flow.

From previous research it is evident that implementing IID policies requires a greater sensitivity to relational and spatial interactions, supported by officials with sufficient experience, credibility and technical ability to facilitate inclusive processes. For some public entities, such as dedicated incubators and innovation agencies, support for IID may be a core function. However, building these capacities and implementing these activities at scale requires time and substantial human resources. Altenburg goes as far as arguing that instead of extensive investment in various micro and meso-level instruments, there is a need to 'design innovation policies in a way that reflects the ability of governments' - which could mean a stronger emphasis on basic market enablers, such as ensuring trustworthy and efficient business registration processes (2009: 46). At the same time, though, much of how state organs support IID is about how they are able to respond when activist grassroot movements or civil-society organisations (CSOs) engage them to address local or national development issues (Fressoli et al. 2014). CSOs tend to be entrepreneurial in character, which leads to tensions with more administrative and process-oriented public servants. Nonetheless, there are cases where 'friendly' public entities and officials combine a mix of political creativity, public legitimacy and relentless consistency to see actions through (Franco 2008). Persistence is particularly important for winning legal challenges or effecting legislative changes. These entities and capacities are also relevant to growing concerns about the negative impact or harm that is resulting from emerging technologies (Schillo \& Robinson 2017) for which there is likely a need for a mix of soft (e.g. codes of practice) and hard law instruments (Lee \& Petts 2013). Independent oversight entities and human rights agencies are typically in a better position to do this kind of work. For public organisations innovating around oversight, audit, prosecution and human rights, important capacities include an ability to acquire necessary professional skills, secure core funding, build leadership stability, retain institutional memory and ensure transparency.

The following section explores how public sector entities in South Africa are managing innovation, including how this relates to inclusive development outcomes. The section starts by providing context on the country's broader shift in STI policy thinking, focusing on the 
recent calls for a more demand-side orientation and an expansion of the national system of innovation (NSI) to enrol additional government actors.

\section{South African policy and programmes}

In the post-apartheid transition to new innovation structures, South Africa has seen significant institutional development and diversification (OECD 2007: 200-209). Generally, the earlier policy approach focused on direct R\&D investment and supply-side instruments, largely under the influence of neoliberal macroeconomic policies, which is seen to have led to a number of missed opportunities. For example, there were no significant initiatives to link large-scale housing development programmes with the development of indigenous technologies relevant to local contexts (Scerri \& Lastres 2013: 256).

More recently, the 2019 STI White Paper suggests a shift in policy approach away from direct, supply-side-focused R\&D funding, towards active partnering with industry, government departments and civil society through a stronger demand-side focus (DSI 2019: 33). This appears to come from a recognition that STI impact depends on buy-in from other parts of government (DSI 2019: 25), a desire to more directly improve economic competitiveness in target sectors (DSI 2019: 27), the need for transdisciplinary approaches to solve complex challenges (DSI 2019: 16), and an emphasis on achieving inclusive development outcomes by working more directly with civil society (DSI 2019: 24). Ultimately this forms part of an 'expanded' NSI, which depends on the strengthening of 'government's role as an enabler for innovation' (DSI 2019: 41).

In the following sub-sections, selected categories of public entities are examined to understand how they relate to these high-level principles and policy directions that the DSI and national public service entities are espousing.

\section{Universities and research councils}

For the STI White Paper, in the expanded NSI, the role of universities in STI continues to be 'central', but as part of a more dispersed research and innovation environment:

\section{Universities will continue to play a leading central role in research in South Africa. However, in line with global trends, other organisations such as science councils, non-governmental organisations, state-owned entities (SOES) and other privately funded institutions are increasingly becoming sites of research and innovation activities (DSI 2019:15)}

It may be argued that, from a research perspective, research councils have been playing a similarly 'leading central' role, especially through their focus on what the Human Sciences Research Council (HSRC) calls 'engaged research' which is 'solution-orientated' and 'policylinked, highly engaged' for government, private sector and civil society (HSRC 2020: 11). Competition for relevance from councils and universities has increased, with a number of vice chancellors and CEOs applying rhetorical, conceptual and governance innovation to (re)position universities as relevant to emerging technological developments and their impact on pressing social and economic challenges (e.g. Marwala 2019). 
The Council for Scientific and Industrial Research (CSIR) mainly pursues impact through the commercialisation of technologies for industrial development and knowledge transfer to enable a capable state (CSIR 2020a: 7). As the largest research council in the country, the CSIR supports a diversity of innovation activities, often in partnership with universities and SOEs, from basic research to technology localisation with SOEs and promoting alternative production methods (CSIR 2020a). Classified as a Schedule 3B SOE under the Public Finance Management Act (PFMA) No. 1 of 1999, the CSIR is different to other research councils in not being financed fully or substantially by Treasury (Bronstein \& Olivier 2015). Whilst largely self-sufficient, the CSIR is still required to establish a shareholder compact with the executive authority, which determines performance expectations (CSIR 2020b).

For both universities and science or research councils, 'impact' has traditionally been realised through senior research and management relationships with industry and the public sector, typically along sector lines. However, in an effort to formalise the use of public-funded research, and modelled on Bayh-Dole and similar legislation globally, the Intellectual Property Rights from Publicly Financed Research and Development (IPR Act) No. 51 was promulgated in 2008. The IPR Act included the establishment of a National Intellectual Property Management Office (NIPMO) and Technology Transfer Offices (TTOs) at institutions to oversee compliance and reporting on the disclosure and protection of IP created by or with researchers.

To fulfil the compliance requirement, most TTOs depend on highly qualified individuals and legal expertise, although often outsourced to legal firms (Mustapha et al. 2017: 19-21), which means that a high proportion of operational costs (around 50\%) are allocated to the evaluation and formal registration of IP (Mustapha et al. 2017: 26). Another key activity is that of 'marketing' and commercialisation of IP, with responsible individuals seeking out technology licensing partners in the private sector and in SOEs (Mustapha et al. 2017: 1921). As seen internationally, better-resourced universities have established incubators to support new venture creation as a growing licensee for research (e.g. LaunchLab n.d.; Tuksnovation n.d.). TTOs either incorporate or work with a diverse mix of professionals and administrators involved in impact-related work across the wider university structure. These individuals coordinate researcher involvement in various external-facing activities, such as designing and running short courses for industry and government, research contracts, and community engagement (Kruss 2012).

From an inclusive development perspective, community engagement has become an increasingly important vehicle for exploring and demonstrating university impact in a more direct form. Beyond the largely voluntary and ad-hoc engagement work by individual staff and research groups (from national policy committees to community-based organisations), many universities are looking to position themselves more strategically as a development advisor and facilitator for communities or a region. This is especially relevant to historically disadvantaged universities located in marginalised and rural areas of the country, which see their local knowledge and credibility as an opportunity to attract public, private and nongovernmental partners to work on development issues. As part of a strategic agenda, universities may adopt more structured models of engagement to guide researchers towards authentic and sustainable co-creation of solutions to local challenges. Embedding university cooperation in local municipality and provincial government plans is a key feature 
of this approach (Jacobs et al. 2019). However, the way in which universities develop 'interaction capabilities' is likely to vary. From a comparative study of two research universities, Kruss finds that both organisations promoted social engagement as a priority at all decision-making levels. Differences were evident in the way they facilitated adoption of social engagement practices, with 'one relying on academic compliance with formal procedures and the other relying on a diffusion, brokerage and advocacy model' (2010: 20).

The strategic opportunity related to inclusive development is also reflected in RRI discourse, as outlined in the STI White Paper (DSI 2019):

\section{A South African focus on RRI would help local researchers to collaborate and compete with their foreign counterparts in a world where ethical concerns (such as fair trade) and environmental concerns (such as emission standards) are increasingly influencing competitiveness (STI White Paper 2019:6)}

Aside from being a competitive advantage, basing itself on the European Union (EU) RRI framework, the STI White Paper anticipates, amongst others, 'increasing open access to STI' and 'developing the required governance framework to drive the RRI agenda across the NSI' (DSI 2019: 19). These pillars connect with similar goals of mainstreaming IID (Petersen \& Kruss 2019) and facilitating open research and innovation as enablers of a 'whole-of-society approach to innovation' (DSI 2019: 33).

Practically, this also means that research data and research infrastructure need to become more open (DSI 2019: 58). One example in the National Integrated Cyberinfrastructure System (NICIS) is the South African National Research Network (SANReN). SANReN provides low-cost, high-speed connectivity to research and education organisations, including to, often quite remote, Technical and Vocational Education and Training (TVET) colleges (PMG 2018). SANReN has significant competing demands in needing to ensure the inclusion of geographically dispersed organisations and having to manage the advanced science and innovation requirements of 'large-scale global research and science projects' (NICIS n.d.). Through both its broad reach and its association with globally prestigious projects such as the Square Kilometre Array, SANReN (and the wider NICIS and National Research Foundation-supported group of research infrastructure projects) appears to maintain strong political support (PMG 2018). This reflects a similar politically complex path that universities and research councils need to navigate in seeking to enhance their 'world-class' status whilst expanding inclusivity.

\section{Innovation agencies and hubs}

Public innovation agencies and hubs are a more recent addition to South Africa's NSI. One of the first, and largest, entities established was The Innovation Hub (TIH), a provincial government-funded science and technology park, which runs a variety of innovation support programmes and incubates over 200 start-up companies (TIH n.d.). Together with the national Technology Innovation Agency (TIA) and many other regional innovation intermediaries, TIH has elevated the profile of innovation in the country. Start-up incubation and enterprise development have become a central feature of innovation and IID support. Typically this involves supply-side assistance, such as grant funding, vouchers for technical 
services, and access to public-financed intellectual property. Increasingly, attention is directed towards linking emerging entrepreneurs with customers in government and corporates.

These activities form part of what the STI White Paper sees as 'Specific support for SMEs', which includes incubation and mentoring focusing on SMEs in 'informal settlements, rural areas and cooperatives', and addressing 'regulatory hurdles, as well as burdensome administration and legal requirements' (DSI 2019: 35). In recent years, with the promulgation of the IPR Act, a stronger emphasis has been placed on providing 'access mechanisms' to the IPR registration system so that 'all innovations, regardless of source and nature, may find protection, where relevant and desirable' (DSI 2019: 33). Underlying this statement is an explicit attempt to assist marginalised innovators derive commercial benefit from their works, and to prevent unregulated harvesting and exploitation of indigenous IP by external actors.

For public agencies and hubs, there is a strong dependence on running fair, transparent and efficient administrative processes to facilitate the registration of new businesses and IP or in allocating funding. Normally this involves standardised administrative tools and routines. To reduce risk and maintain an arms-length relationship, these processes tend to be inflexible and time consuming (with extensive information and review requirements), leading to the perception and reality of 'red-tape' that is anathema to innovators and entrepreneurs (Abrahams 2020).

In addition to these administrative functions, agencies and hubs are expected to play a more hands-on mediating role. To expand the reach of incubators to underserved areas - as done by TIH with its eKasi Labs programme, the Small Enterprise Development Agency (SEDA) and TIA IID - there is a heavy dependence on accessing or building facilities and engaging local youth, women or business associations for the identification and enrolment of participants. This often requires partnering with local municipalities (SAnews 2020; Eyewitness News 2016). In this role, incubator staff need political, policy and administrative skills to navigate a somewhat complex inter-governmental relations environment, and then deliver on outputs (Jacobs et al. 2019).

Given that most incubators and hubs focus on early stage innovators and entrepreneurs, they are also expected to facilitate user, partner and funder interaction by arranging meetings with potential customers or co-sponsors. They may also draw on design thinking, lean start-up and community engagement tools to enable user engagement. Incubators often contract external mentors, who are typically associated with the wider enterprise and supplier development community, and which tend to provide generic business advice. However, for the mentoring of technology-oriented innovators (which can range from university research groups to social entrepreneurs in informal settlements), there is a critical need for the translation of prototype products and services into small and mediumscale client or donor-funded pilots. For this support, project management, compliance, IP guidance, certification and technical business development mentoring is required (Abrahams 2020; Hart et al. 2020). 
Amongst the government-linked business incubators and innovation enablers, there is substantial organisational and administrative variety. As an example, Innovate Durban has been established with funding from the eThekwini Municipality (2017), but by being established as a non-profit organisation, it has significant flexibility around financial management and human resource (HR) routines. More broadly, Schedule $3 A$ public entities as listed in the PFMA, such as TIA, TIH (as a subsidiary of the Gauteng Growth and Development Agency), and SEDA are subject to similar laws and, therefore, routines related to financial management. Whilst these entities are largely 'dependent' on Treasury funding and budget approval, they do have some independence similar to the 'major' Schedule 2 SOEs (Bronstein \& Olivier 2015). These entities are able to generate their own revenue through rentals, in the case of $\mathrm{TIH}$, and investment returns in the case of TIA (Technology Innovation Agency Act No. 26 of 2008), and have some flexibility in the remuneration of staff (Maloa 2020). As a result, there is a relatively strong emphasis on selling services, mobilising co-funding and bidding for contracts with the private sector, government departments and investees. All of these activities can create a tension in priorities when looking to serve more marginalised innovators and municipalities, which are less likely to provide a financial return. The same balancing of priorities is evident in specific programmes, such as $\mathrm{TIH}^{\prime}$ s OpenIX, which runs open innovation challenges on a web platform to 'provide solutions' for industry and government clients, whilst also 'creating opportunities for solution providers and entrepreneurs from the region' (OpenIX n.d.).

\section{Innovation funders}

National Treasury - which sets the rules for government procurement through the PFMA, Municipal Finance Management Act (MFMA) No. 56 of 2003 and related legislation - and a group of related public entities are critical to how state funds are allocated directly and indirectly (via SOEs and other state entities) to innovation activities. These entities include the Auditor General, which reports on compliance with Treasury rules; the Department of Trade, Industry and Competition (DTIC), which designs and administers several large competitiveness and industry development incentives; the South African Revenue Service (SARS), which implemented tax-related instruments such as the recently discontinued 121 manufacturing and 12J venture capital incentives (National Treasury 2022; South Africa Startup Act 2021); and the Industrial Development Corporation (IDC) and Development Bank of South Africa (DBSA) as two large development finance institutions.

For innovation and inclusive development, the DTIC, working with above entities, is of particular importance through three key activities. First, through investment and export promotion programmes and by facilitating participation in international trade fairs, the DTIC is exposing local enterprises to potential partners and ideas globally (DTICa n.d.). Second, through the administration of Special Economic Zones, the DTIC influences the spatial distribution of economic activity and the location of innovation-oriented competitiveness improvement activities (DTICb n.d.). Third, the DTIC oversees Broad-Based Black Economic Empowerment (B-BBEE) policy for which the fundamental objective is 'to advance economic transformation and enhance the economic participation of black people in the South African economy' (DTICc n.d.). B-BBEE, together with the Preferential Procurement Policy Framework Act of 2000 (PPPFA), have sought to leverage procurement to accelerate localisation and transformation across a range of sectors. This legislation has been 
supported by supply and demand-side initiatives driven by other entities, such as the Department of Public Enterprise's (DPE) Competitive Supplier Development Programme (CSDP) which aimed to 'leverage [State Owned Enterprise (SOE)] expenditure to develop competitive national supplier industries, and where possible, to build export capabilities' (DPE 2007: 2). However, the intent of these policies and programmes have not been fully realised, largely due to weak enforcement of localisation requirements (Andreoni et al. 2021). Enforcement issues aside, through procurement-related incentives, private sector companies have contributed to the rapid growth of enterprise and supplier development programmes and incubators, many of which have a technology or innovation orientation (Masutha \& Rogerson 2014). In addition, following alignment of B-BBEE and preferential procurement policies, government entities are empowered to direct spending towards black-owned enterprises (DTICd n.d.). The ability of qualifying enterprises to benefit from these policies depends on government's ability to minimise abuse (such as 'fronting' by white-controlled enterprises) and ensure efficient administration (such as allocating B-BBEE certificates).

Although B-BBEE and procurement policies are intended to favour SMEs and there are smaller innovation funding instruments, such as the Support Programme for Industrial Innovation (SPII) (DTICe n.d.) and a Gro-E Youth Scheme (IDC n.d.), much of the attention of these national entities is directed towards larger-scale spending and projects implemented by relatively established firms using proven technologies. The dominant routine in these entities is financial management related to investment decisions, which seek a mix of development potential (e.g. job creation, exports) and return on investment. In addition, newer multi-sector instruments, such as the sovereign innovation fund (DSI 2019: 65), require significant political and policy capacities to build trust and enrol partners.

To address earlier-stage innovation funding needs, TIA was established as a consolidation of a number of innovation funding entities (Kahn 2013) and generally supports earlier stage financing of technology-oriented innovation. One instrument that has seen significant growth is the TIA Seed Fund, which has mainly targeted the commercialisation of university research by working with TTOs, but also supports innovation by small enterprises (TIAa n.d.). The Seed Fund has traditionally allocated funding via TTOs and certain business incubators such as TIH (TIH n.d.).

From a public sector and inclusive development perspective, there has been a substantial expansion in TIA's funding responsibilities: the Youth Technology Innovation Programme (YTIP) has existed for several years as a voucher-based funding mechanism, enabling youthled enterprises to access various services within a network of providers. More recently, TIA has been managing a ring-fenced pilot programme of DSI on IID specifically, which aims to 'establish community-based innovation centres that develop solutions through co-creation approaches, geared for local challenges', to 'support grassroots innovators that have simple, social innovations' and to 'support the innovation for local economic development strategies of districts and municipalities' (TIAb n.d.). In addition, the same partners have (re)launched a Technology Acquisition and Deployment Fund (TADF) pilot programme to 'facilitate the commercialization of locally developed technologies, promoting their uptake by government and its entities i.e public sector, to improve their operations, enhance service delivery and address pressing socio-economic challenges' (TIAC 2020). This type of 
programme requires significant consulting-type expertise for engaging with government departments to identify and articulate their innovation requirements.

Participants in these early stage programmes are generally seen as a pipeline for later-stage TIA, IDC and DTI instruments (DTICf n.d.). Whilst the financial management routines of later stage TIA instruments have similarities to those of the IDC, early stage TIA and incubator funding is generally grant-based, with no expectation of financial returns. As a result, the administration of these funds tends to be more flexible, and often delivered in partnership with local incubator programmes, which aim to support engagement with and development of a user base - including 'promoting uptake' - which can hopefully be monetised. TIA units leading the Seed Fund, YTIP, IID and TADF programmes are therefore more likely to engage collaboratively with intermediaries, such as $\mathrm{TIH}$, to review candidates and identify pathways for adoption and/ or commercialisation as with previous initiatives of a related kind (Senyolo et al. 2018; Hart et al. 2020; Jacobs et al. 2019).

\section{Regulatory and oversight entities}

The previous sub-sections have described an array of innovation-related instruments and intermediaries, as well as their relationship to inclusive development outcomes. Effective implementation of these instruments, as well as broader oversight as to the benefits and harms of innovation, depends on a number of other specialised public organisations with diverse capacities.

As a more established actor in the innovation space, the Companies and Intellectual Property Commission (CIPC) is responsible for, amongst others, the registration of companies and of intellectual property such as trademarks and patents (CIPCa n.d.). The process of registering a company and, the now tightly coupled, registration with SARS, setup of company bank accounts and registration on Treasury's Central Supplier Database (CSD), is critical for emerging enterprises to be able to bid for and be awarded contracts, especially with government entities (National Treasury 2016). For innovators, the effectiveness of IP administration is similarly important. As a result, efficiency, reliability, transparency and accountability are all key for how CIPC (and SARS with the CSD) operate.

However, the CIPC in particular has had to navigate a difficult transition post-Apartheid. As described by Chipkin and Lipietz (2012), in seeking to undo the bureaucracy and establish the CIPC as a 'business' entity, along with leadership's efforts 'to be sincerely innovative' in developing and implementing a business case for the organisation (2012: 22); the CIPC management disrupted its core operations. In contrast, they highlight how with SARS:

$$
\begin{aligned}
& \text { 'While ostensibly a victory of the NPM model, in that [SARS] sits outside } \\
& \text { the public service and that skilled personnel are paid market related } \\
& \text { salaries, many of its major achievements have come from very careful } \\
& \text { attention to the core functions and processes of revenue collection' (2012: } \\
& \text { 23). }
\end{aligned}
$$

Whilst reliable operation is central to how CIPC and SARS enable innovation, various other entities are having a more strategic influence over emerging digital technologies and related innovation and inclusive development outcomes. South Africa's Competition Commission 
(CC) recently published a draft report on 'Competition in the Digital Economy' under the rationale that 'the digital economy in developing countries already threatens a new era of global concentration and, with it, the further marginalisation of vulnerable countries and businesses' (CCa 2020: 4). The intent of the CC is evident in its successful implementation of findings from an inquiry into data costs. This included a settlement with Vodacom on the reduction of retail pricing and an extension of zero-rating to additional 'pro-poor' websites ( $\mathrm{CCb}$ n.d.). Together with the Competition Tribunal, the $\mathrm{CC}$ has the authority to impose various sanctions on companies, including administrative penalties and 'ordering a party to supply or distribute goods or services to another party' (Competition Act No. 89 of 1998). These types of orders are important for enabling market access for and competition by emerging technology enterprises.

As highlighted by the $\mathrm{CC}$, including in the digital economy report, data and related innovation has become a key concern for several regulatory entities. The Information Regulator (IR), which has recently transitioned out of its temporary home in the South African Human Rights Council (SAHRC), has dual mandates: the promotion of access to information and the protection of personal information (IR 2020). Access to information and, more specifically, access to government and other 'big' data is regarded as a key enabler for technological innovation; both for the expansion and improvement of egovernment services, but also for enabling social impact innovation by digital entrepreneurs (DCDT 2017; OGP 2019). However, these policies and programmes also emphasise that the opening of information and data must be complemented by appropriate privacy and security controls.

As the IR notes, 'there is an unprecedented retention of personal information in the digital space' and as a result, for innovations such as artificial intelligence, which are built on big data, 'such innovations should comply with [the Protection of Personal Information Act (POPIA) No. 4 of 2013]' (IR 2020: 13). The IR will require a strengthening of administrative capacity as public and private entities seek to comply with the various regulations, and will need to continue building its strategic and legal capacity for anticipation emerging issues, such as around artificial intelligence. Through these activities, the IR has a critical role to play in building and sustaining trust in South African information systems, as a requirement for interconnection, data sharing and e-commerce with other parts of the world (Blom \& Nkado 2020). Whilst the IR has substantial independence in only being accountable to the National Assembly, the Constitution and the law - and can enforce compliance with relevant regulations - it has been dependent on Department of Justice and Constitutional Development policies and systems, and is funded out of Treasury allocations for which the 'unavailability of adequate budget remains a huge challenge' (IR 2020: 3). In addition, to support its strategic capacity, the IR may need to consider ways of responding to a fastmoving innovation environment, such as by hosting or participating in regulatory sandboxes as a way to explore and anticipate possible challenges whilst also educating innovators on POPIA regulations (Mostert 2020).

More broadly, entities such as the SAHRC, are looking to engage with researchers and the public on topics related to data, artificial intelligence and the 'fourth industrial revolution' $(4 I R)$ so that human rights are respected and democratic governance is not threatened by the adoption of emerging technologies (SAHRC 2020). The SAHRC is empowered by its 
Constitutional and legal status and, through its Legal Services Unit, provides legal advice and seeks redress through the courts for victims of human rights violations. Given the emerging nature of many technologies and associated issues, the SAHRC, courts and judges will need to be equipped to handle matters associated with these platforms and develop precedent that can extend the interpretation of existing laws. Again, this points to the need for a strategic and pre-emptive approach in the human rights and legal community, which could include benchmarking with international precedent amongst other actions (Razzano 2021).

In addition, the increasing concern with human rights and potential harm from innovation activities and the 4IR, is echoed in various policy arenas, and somewhat ironically in conspiracy theories propagating through social media. It is, therefore, a key area in which the DSI and innovation stakeholders will need strong convening capacities to work with entities such as the SAHRC and facilitate meaningful awareness and discussion.

\section{Discussion and conclusion}

More than a decade ago, the OECD noted that South Africa's innovation system was characterised by significant 'organizational creativity in building new structures to support new aims' (OECD 2007: 200). If anything, this creativity has expanded to new sectors and organisational forms, especially in the intermediary and policy sub-system (Cooke 2008). The above case study is, therefore, a small sample of the myriad organisations and units involved in policy development and programme implementation, and only those that have been established as public entities. In this sample, it is possible to start seeing the pressure that growing innovation, and now inclusive innovation expectations are starting to exert within these public entities, from researchers to procurement officials.

In Table 1 below, drawing on the case study above, the main routines, capacities and legitimacy related to innovation are summarised. The table also provides an indication of emerging and possible actions towards addressing inclusive development outcomes. The examples from the case study are mapped to the framework developed in the conceptual discussion and outlined in Karo and Kattel (2016a; 2016b; 2015). Where new attributes need to be added to the framework, these are highlighted with a * when first used. In each cell, whilst many routines, capacities and legitimisers may be relevant, only selected characteristics are highlighted. By doing this, the table seeks to provide an initial insight that can form the basis for more in-depth validation and research. 
Table 1: Case study examples mapped to routines, legitimacy and capacity from Karo and Kattel (2016a; 2016b), with inclusion actions

\begin{tabular}{|c|c|c|c|c|c|c|c|}
\hline $\begin{array}{l}\text { Organisation } \\
\text { or division }\end{array}$ & $\begin{array}{l}\text { Organisation } \\
\text { or division } \\
\text { type }\end{array}$ & Key Individual* & $\begin{array}{l}\text { Innovation } \\
\text { goals* }\end{array}$ & Key routine(s) & Legitimacy & Key capacities & $\begin{array}{l}\text { Inclusive } \\
\text { development actions* }\end{array}$ \\
\hline $\begin{array}{l}\text { Innovation } \\
\text { agencies and } \\
\text { hubs }\end{array}$ & $\begin{array}{l}\text { Professional } \\
\text { machine }\end{array}$ & CEO & $\begin{array}{l}\text { Economic } \\
\text { impact; } \\
\text { political } \\
\text { recognition for } \\
\text { leading } \\
\text { innovation } \\
\end{array}$ & $\begin{array}{l}\text { Strategic management: } \\
\text { 'Corporate' portfolio } \\
\text { strategy and divisions or } \\
\text { programmes with } \\
\text { individual strategies }\end{array}$ & $\begin{array}{l}\text { Investor and } \\
\text { customer } \\
\text { relationships }\end{array}$ & $\begin{array}{l}\text { Commercial; } \\
\text { technical }\end{array}$ & $\begin{array}{l}\text { Extend reach of } \\
\text { innovation } \\
\text { programmes }\end{array}$ \\
\hline $\begin{array}{l}\text { Enterprise } \\
\text { development/ } \\
\text { incubation } \\
\text { organisation } \\
\text { or division } \\
\text { (e.g. SEDA, } \\
\text { TIH) }\end{array}$ & $\begin{array}{l}\text { Professional } \\
\text { machine } \rightarrow \\
\text { Entrepreneurial }\end{array}$ & $\begin{array}{l}\text { Division or } \\
\text { programme head }\end{array}$ & $\begin{array}{l}\text { New business } \\
\text { creation; } \\
\text { business } \\
\text { investment } \rightarrow \\
\text { business } \\
\text { revenue }\end{array}$ & $\begin{array}{l}\text { Coordination: } \\
\text { Standardisation of work } \\
\text { processes } \rightarrow \text { mutual } \\
\text { adjustment }\end{array}$ & $\begin{array}{l}\text { Access to investors } \\
\text { and customers; } \\
\text { pipeline of emerging } \\
\text { entrepreneurs for } \\
\text { investors }\end{array}$ & $\begin{array}{l}\text { Commercial; } \\
\text { technical }\end{array}$ & $\begin{array}{l}\text { Extend reach of } \\
\text { incubation and } \\
\text { investment facilitation } \\
\text { programmes to } \\
\text { marginalised areas }\end{array}$ \\
\hline $\begin{array}{l}\text { Innovation } \\
\text { facilitation } \\
\text { organisation } \\
\text { or division } \\
\text { (e.g. TIH) }\end{array}$ & Entrepreneurial & $\begin{array}{l}\text { Division or } \\
\text { programme head }\end{array}$ & $\begin{array}{l}\text { New provider- } \\
\text { customer } \\
\text { projects }\end{array}$ & $\begin{array}{l}\text { Coordination: Openness; } \\
\text { Financial management: } \\
\text { Process oriented } \rightarrow \\
\text { flexible; Personnel } \\
\text { management: Needs- } \\
\text { based recruitment and } \\
\text { development }\end{array}$ & $\begin{array}{l}\text { Access to potential } \\
\text { customers; access to } \\
\text { researchers and } \\
\text { innovators; } \\
\text { Innovation processes } \\
\text { and IPR knowledge; } \\
\text { 'independence' from } \\
\text { government } \\
\text { bureaucracy }\end{array}$ & $\begin{array}{l}\text { Technical; } \\
\text { policy }\end{array}$ & $\begin{array}{l}\text { Identify opportunities } \\
\text { for incremental/ local } \\
\text { innovation; Facilitate } \\
\text { public sector and } \\
\text { social innovation } \\
\text { involving CSOs }\end{array}$ \\
\hline $\begin{array}{l}\text { Innovation } \\
\text { funders (e.g. } \\
\text { TIA, IDC, DTIC) }\end{array}$ & $\begin{array}{l}\text { Diversified } \\
\text { machine }\end{array}$ & CEO & $\begin{array}{l}\text { Economic } \\
\text { impact; } \\
\text { political } \\
\text { recognition } \\
\end{array}$ & $\begin{array}{l}\text { Strategic management: } \\
\text { 'Corporate' portfolio } \\
\text { strategy and divisions } \\
\text { with individual strategies } \\
\end{array}$ & $\begin{array}{l}\text { Funding, co-investor } \\
\text { relationships }\end{array}$ & $\begin{array}{l}\text { Commercial; } \\
\text { policy; } \\
\text { political }\end{array}$ & $\begin{array}{l}\text { Identify value chains } \\
\text { for diversification; } \\
\text { Invest in public and } \\
\text { social innovation } \\
\end{array}$ \\
\hline $\begin{array}{l}\text { Sector } \\
\text { investment/ } \\
\text { incentives } \\
\text { organisations }\end{array}$ & $\begin{array}{l}\text { Diversified } \\
\text { machine }\end{array}$ & Division head & $\begin{array}{l}\text { Sustainable } \\
\text { businesses }\end{array}$ & $\begin{array}{l}\text { Financial management: } \\
\text { Process and output } \\
\text { oriented; Coordination: } \\
\text { Standardisation of skills } \\
\rightarrow \text { Openness }\end{array}$ & $\begin{array}{l}\text { Funding; co-investor } \\
\text { and customer } \\
\text { relationships; market } \\
\text { knowledge }\end{array}$ & $\begin{array}{l}\text { Commercial; } \\
\text { administrative }\end{array}$ & $\begin{array}{l}\text { Earlier stage, hands- } \\
\text { on (equity) } \\
\text { investment } \\
\text { relationships, working } \\
\text { with incubators; } \\
\end{array}$ \\
\hline
\end{tabular}




\begin{tabular}{|c|c|c|c|c|c|c|c|}
\hline $\begin{array}{l}\text { Organisation } \\
\text { or division }\end{array}$ & $\begin{array}{l}\text { Organisation } \\
\text { or division } \\
\text { type }\end{array}$ & Key Individual* & $\begin{array}{l}\text { Innovation } \\
\text { goals* }\end{array}$ & Key routine(s) & Legitimacy & Key capacities & $\begin{array}{l}\text { Inclusive } \\
\text { development actions* }\end{array}$ \\
\hline $\begin{array}{l}\text { and divisions } \\
\text { (e.g. IDC, DTIC) }\end{array}$ & & & & & & & $\begin{array}{l}\text { facilitate investor and } \\
\text { customer engagement }\end{array}$ \\
\hline $\begin{array}{l}\text { Early-stage } \\
\text { investment } \\
\text { organisations } \\
\text { and divisions } \\
\text { (e.g. TIA, DTIC } \\
\text { SPII) }\end{array}$ & $\begin{array}{l}\text { Professional } \\
\text { machine }\end{array}$ & Division head & $\begin{array}{l}\text { Increased } \\
\text { pipeline } \\
\text { and/or better } \\
\text { quality } \\
\text { innovators }\end{array}$ & $\begin{array}{l}\text { Financial management: } \\
\text { Process-oriented } \rightarrow \\
\text { professional autonomy }\end{array}$ & $\begin{array}{l}\text { Funding; co-investor } \\
\text { and customer } \\
\text { relationships; IPR } \\
\text { knowledge }\end{array}$ & $\begin{array}{l}\text { Administrative; } \\
\text { technical }\end{array}$ & $\begin{array}{l}\text { Work with incubators } \\
\text { to grow reach and } \\
\text { improve quality; } \\
\text { diversify types of } \\
\text { support and } \\
\text { candidates }\end{array}$ \\
\hline $\begin{array}{l}\text { Regulatory } \\
\text { and oversight } \\
\text { entities }\end{array}$ & Varies & & & & & & \\
\hline $\begin{array}{l}\text { Business and } \\
\text { IP licensing } \\
\text { organisations } \\
\text { and divisions } \\
\text { (e.g. } \mathrm{CIPC} \text { ) }\end{array}$ & $\begin{array}{l}\text { Diversified } \\
\text { machine }\end{array}$ & $\begin{array}{l}\text { Commissioner/ } \\
\text { CEO }\end{array}$ & $\begin{array}{l}\text { Reduce time } \\
\text { and cost to } \\
\text { register } \\
\text { business or IP }\end{array}$ & $\begin{array}{l}\text { Coordination routines: } \\
\text { standardisation of work } \\
\text { processes and outputs } \rightarrow \\
\text { professional development } \\
\text { (IP opinions) }\end{array}$ & Legal (and efficiency) & Administrative & $\begin{array}{l}\text { Improve accessibility } \\
\text { and useability of } \\
\text { registration systems; } \\
\text { Expand education } \\
\text { initiatives }\end{array}$ \\
\hline $\begin{array}{l}\text { Economic and } \\
\text { labour } \\
\text { regulation } \\
\text { organisations } \\
\text { and divisions } \\
\text { (e.g. CC) }\end{array}$ & Professional & $\begin{array}{l}\text { Commissioner/ } \\
\text { CEO }\end{array}$ & $\begin{array}{l}\text { Increase and } \\
\text { diversify } \\
\text { participation in } \\
\text { markets; } \\
\text { Reduce labour } \\
\text { exploitation }\end{array}$ & $\begin{array}{l}\text { Personnel management: } \\
\text { variety and mix of skills, } \\
\text { openness to learning; } \\
\text { Flexible recruitment; Peer } \\
\text { review. }\end{array}$ & $\begin{array}{l}\text { Legal and technical } \\
\text { knowledge }\end{array}$ & $\begin{array}{l}\text { Policy; } \\
\text { technical }\end{array}$ & $\begin{array}{l}\text { Open learning to } \\
\text { identify emerging } \\
\text { areas of market } \\
\text { dominance or labour } \\
\text { exploitation e.g. data, } \\
\text { gig economy }\end{array}$ \\
\hline $\begin{array}{l}\text { Human rights } \\
\text { organisations } \\
\text { and divisions } \\
\text { (e.g. IR, } \\
\text { SAHRC) }\end{array}$ & Professional & $\begin{array}{l}\text { Commissioner/ } \\
\text { CEO }\end{array}$ & $\begin{array}{l}\text { Prevent harm } \\
\text { from emerging } \\
\text { tech; Use tech } \\
\text { to empower } \\
\text { marginalised }\end{array}$ & (Similar to above) & (Similar to above) & $\begin{array}{l}\text { Similar to } \\
\text { above }\end{array}$ & $\begin{array}{l}\text { Community and CSO } \\
\text { relationships to } \\
\text { identify areas of harm; } \\
\text { Enable beneficial use } \\
\text { of tech }\end{array}$ \\
\hline
\end{tabular}




\begin{tabular}{|c|c|c|c|c|c|c|c|}
\hline $\begin{array}{l}\text { Organisation } \\
\text { or division }\end{array}$ & $\begin{array}{l}\text { Organisation } \\
\text { or division } \\
\text { type }\end{array}$ & Key Individual* & $\begin{array}{l}\text { Innovation } \\
\text { goals* }\end{array}$ & Key routine(s) & Legitimacy & Key capacities & $\begin{array}{l}\text { Inclusive } \\
\text { development actions* }\end{array}$ \\
\hline $\begin{array}{l}\text { Universities } \\
\text { and research } \\
\text { councils (e.g. } \\
\text { HSRC, CSIR) }\end{array}$ & Professional & $\begin{array}{l}\text { Deputy vice } \\
\text { chancellor } \\
\text { research }\end{array}$ & $\begin{array}{l}\text { Social or } \\
\text { industrial } \\
\text { impact; } \\
\text { Research } \\
\text { revenue }\end{array}$ & $\begin{array}{l}\text { Strategic management: } \\
\text { Stable, many fragmented } \\
\text { strategies by professional } \\
\text { judgment and collective } \\
\text { choice }\end{array}$ & $\begin{array}{l}\text { Intellectual } \\
\text { recognition; } \\
\text { Relevance to } \\
\text { industry or society } \\
\text { needs }\end{array}$ & $\begin{array}{l}\text { Political } \\
\text { (innovation } \\
\text { narratives/ } \\
\text { rhetoric); } \\
\text { policy }\end{array}$ & $\begin{array}{l}\text { Localise strategic } \\
\text { management and } \\
\text { production; Diversify } \\
\text { personnel } \\
\text { management }\end{array}$ \\
\hline $\begin{array}{l}\text { Research } \\
\text { division }\end{array}$ & Professional & $\begin{array}{l}\text { Division or unit } \\
\text { head }\end{array}$ & $\begin{array}{l}\text { Research } \\
\text { revenue; Social } \\
\text { or industrial } \\
\text { impact }\end{array}$ & $\begin{array}{l}\text { Research: Open search } \\
\text { and validation processes } \\
\text { including design, field } \\
\text { work, conferences, peer } \\
\text { review }\end{array}$ & $\begin{array}{l}\text { Intellectual academic } \\
\text { reputation; } \\
\text { Relevance to } \\
\text { industry or society } \\
\text { needs; International } \\
\text { partners }\end{array}$ & $\begin{array}{l}\text { Technical; } \\
\text { commercial; } \\
\text { policy }\end{array}$ & $\begin{array}{l}\text { Identify social or } \\
\text { public funding } \\
\text { sources; Encourage } \\
\text { community action- } \\
\text { research methods; } \\
\text { Mobilise multi- } \\
\text { disciplinary teams }\end{array}$ \\
\hline $\begin{array}{l}\text { Business } \\
\text { development } \\
\text { and contract } \\
\text { management } \\
\text { division }\end{array}$ & $\begin{array}{l}\text { Professional } \\
\text { machine }\end{array}$ & $\begin{array}{l}\text { Bid officer/ } \\
\text { manager }\end{array}$ & $\begin{array}{l}\text { Process } \\
\text { compliance } \\
\text { (e.g. bids, } \\
\text { database } \\
\text { registration); } \\
\text { Budget and } \\
\text { audit } \\
\text { compliance; } \\
\text { Research and } \\
\text { consulting } \\
\text { revenue }\end{array}$ & $\begin{array}{l}\text { Financial management: } \\
\text { Efficiency and process } \\
\text { oriented }\end{array}$ & $\begin{array}{l}\text { Knowledge of } \\
\text { processes and } \\
\text { compliance/ } \\
\text { reporting; } \\
\text { Awareness and } \\
\text { control of budgets }\end{array}$ & $\begin{array}{l}\text { Administrative; } \\
\text { Technical }\end{array}$ & $\begin{array}{l}\text { Identify alternative } \\
\text { funding sources } \\
\text { related to social and } \\
\text { public sector needs; } \\
\text { Build skills on } \\
\text { community-linked } \\
\text { project management } \\
\text { incl. inclusive } \\
\text { reporting }\end{array}$ \\
\hline \multirow[t]{2}{*}{ TTO } & Professional & TTO head/ lawyer & $\begin{array}{l}\text { IPR Act } \\
\text { compliance; } \\
\text { protection of } \\
\text { IP }\end{array}$ & $\begin{array}{l}\text { Coordination: } \\
\text { Standardisation of work } \\
\text { processes and outputs }\end{array}$ & $\begin{array}{l}\text { IP knowledge; Access } \\
\text { to university or } \\
\text { council IP }\end{array}$ & $\begin{array}{l}\text { Technical; } \\
\text { Administrative }\end{array}$ & $\begin{array}{l}\text { Address emerging IP } \\
\text { issues involving } \\
\text { communities e.g. } \\
\text { related to indigenous } \\
\text { knowledge systems } \\
\text { (IKS); Increase } \\
\text { awareness of formal } \\
\text { IP options }\end{array}$ \\
\hline & Entrepreneurial & $\begin{array}{l}\text { Commercialisation } \\
\text { officer }\end{array}$ & $\begin{array}{l}\text { Licensing } \\
\text { revenue; }\end{array}$ & $\begin{array}{l}\text { Personnel management: } \\
\text { flexible recruitment }\end{array}$ & $\begin{array}{l}\text { Access to potential } \\
\text { customers and }\end{array}$ & $\begin{array}{l}\text { Technical; } \\
\text { Commercial }\end{array}$ & $\begin{array}{l}\text { Increase awareness of } \\
\text { IP options including }\end{array}$ \\
\hline
\end{tabular}




\begin{tabular}{|l|l|l|l||l|l|l|}
\hline $\begin{array}{l}\text { Organisation } \\
\text { or division }\end{array}$ & $\begin{array}{l}\text { Organisation } \\
\text { or division } \\
\text { type }\end{array}$ & Key Individual* & $\begin{array}{l}\text { Innovation } \\
\text { goals* }\end{array}$ & Key routine(s) & Legitimacy \\
\hline & & $\begin{array}{l}\text { Startup } \\
\text { creation; Social } \\
\text { or industrial } \\
\text { impact }\end{array}$ & $\begin{array}{l}\text { (often includes } \\
\text { consultants), output- } \\
\text { oriented }\end{array}$ & $\begin{array}{l}\text { Inclusive } \\
\text { development actions* } \\
\text { commercial and legal } \\
\text { issues }\end{array}$ \\
\hline
\end{tabular}


From the above mapping five key themes emerge. First is that there is broad dependence on the effectiveness of administrative capacities and associated routines across incubators, funders and compliance entities. Long application and support timelines are consuming much of the motivation and limited runway of emerging entrepreneurs, as a particularly vulnerable group, so policy actors should be exploring opportunities for encouraging and rewarding improvements in core administrative functions performed by public officials (as much as other, more visible innovation practices).

Second, is that external legitimacy is established in different ways. For example, TTOs are enabled by the IPR Act which gives them stronger legal authority to search and 'claim' IP within the university organisation, and their technical attractiveness to industry and society is enhanced by the relatively ground-breaking IP and skills that are available on campus. A public innovation agency is able to establish technical legitimacy in private and civil society sectors by assembling teams of skilled professionals and consultants with experience outside government. This is possible because of relatively flexible personnel management (recruitment and retention) routines and perceived independence from government bureaucracy. At the same time, these innovation agencies are also able to establish legitimacy with government officials by being sufficiently embedded in and knowledgeable about key public policies and processes, especially financial management routines. In this way they can potentially bridge between sectors, but both the consulting and public policy legitimacy and associated capacities need to be nurtured.

Third, interactive capacity or 'ecological fitness' (Petersen \& Kruss 2020: 58) is an increasingly critical capacity for most public entities, especially intermediaries.

Organisations and divisions need to be open to information on social and industry needs by expanding their networks - including to grassroots civil society organisations. They also need to be able to assemble multi-disciplinary teams which can respond more holistically or systemically to user requirements. Political and relational capacities are necessary for developing partnerships across sector, economic, race, and language boundaries, whilst managing significant power asymmetries which are typical in IID programmes.

Fourth, enhancing trust and opening access to innovation programmes depends on strong enforcement of market rules and protection against harm. For this reason, Competition and Human Rights Commissions along with the Auditor General, which have significant legal and technical legitimacy, have an important role to play. This role can be supported by internal personnel management approaches that can assemble and nurture a mix of professional skills, as well as an openness to learning through open consultation and peer review on draft opinions. Going forward, this openness - including in coordination routines - is important for being able to identify rapidly developing areas of market dominance or labour and other exploitation, such as in control over data or in the gig economy.

Finally, developing the necessary capacities and routines in public sector organisations will require a sensitivity to the dominant culture within an entity, which may require a more compliance-driven or a more advocacy-oriented approach (Kruss 2010). 
In describing the organisational and sub-organisational variety of public sector entities supporting innovation in South Africa, this chapter has identified routines and capacities which are enabling, but also constraining innovation outcomes. The expectation that innovation can support inclusive development is creating additional pressure on public officials to adjust and add to the more traditional administrative and financial management practices. In response, this chapter has sought to demonstrate that the policy language and resources allocated to innovation programmes can better reflect the need to improve or adapt specific routines, capacities and legitimacy in specific areas - whether administrative, technical, commercial or political - as a way to achieve desired outcomes.

\section{References}

Altenburg T (2009) Building inclusive innovation systems in developing countries: challenges for IS research. In B Lundvall, K Joseph, C Chaminade \& J Vang J (eds.) Handbook of innovation systems and developing countries: Building domestic capabilities in a global setting. Cheltenham, UK: Edward Elgar

Andreoni A, Kaziboni L \& Roberts S (2021) Metals, Machinery, and Mining Equipment Industries in South Africa: The Relationship between Power, Governance, and Technological Capabilities. In A Andreoni, P Mondliwa, S Roberts \& F Tregenna (eds.) Structural Transformation in South Africa: The Challenges of Inclusive Industrial Development in a Middle-Income Country. Oxford: Oxford University Press.

Abrahams L (2020) Innovation Entanglement at Three South African Tech Hubs. The African Journal of Information and Communication (AJIC) 26

Bhorat $\mathrm{H}$, Lilenstein K, Oosthuizen M \& Thornton A (2020) Structural transformation, inequality, and inclusive growth in South Africa. United Nations University WIDER Working Paper 2020/50

Blom K \& Nkado E (2020) POPIA, GDPR - or both? Polity. Accessed February 2021, https://www.polity.org.za/article/popia-gdpr-or-both-2020-11-30

Breznitz D, Ornston D \& Samford S (2018) Mission critical: the ends, means, and design of innovation agencies. Industrial and Corporate Change 27(5): 883-896

Bronstein V \& Olivier M (2015) An evaluation of the regulatory framework governing state owned enterprises (SOEs) in the republic of South Africa. Technical Report, The Presidency, Pretoria: Republic of South Africa.

Chipkin I \& Lipietz B (2012) Transforming South Africa's Racial Bureaucracy New Public Management and public sector reform in contemporary South Africa. Public Affairs Research Institute (PARI) Long Essays Number 1

CIPCa (Companies and Intellectual Property Commission) (n.d.) Functions of the Commission. Accessed February 2021, http://www.cipc.co.za/index.php/about/ourfunctions/ 
CCa (Competition Commission) (2020) Competition in the Digital Economy - For Public Comments. Accessed February 2021, http://www.compcom.co.za/wp-

content/uploads/2020/10/Competition-in-the-Digital-Economy-Report-7-September2020.pdf

$\mathrm{CCb}$ (Competition Commission) (n.d.) Data Market Inquiry. Accessed February 2021, http://www.compcom.co.za/newsletter/data-market-inquiry/

Cooke P (2008) Regional innovation systems: origin of the species. International Journal of Technological Learning, Innovation and Development 1 (3): 393-409

CSIR (Council for Scientific and Industrial Research) (2020a) An Overview of the CSIR Strategy. Council for Scientific and Industrial Research: Pretoria, Republic of South Africa.

CSIR (Council for Scientific and Industrial Research) (2020b) CSIR Shareholder's Compact Cycle Commencing 1 April 2020. Council for Scientific and Industrial Research: Pretoria, Republic of South Africa

Cunningham S (2012) The fundamentals of innovation system promotion for development practitioners. Mesopartner Monograph 5

Daniels C, Schot J, Chataway J, Ramirez M, Steinmueller E \& Kanger L (2020) Transformative Innovation Policy: Insights from Colombia, Finland, Norway, South Africa, and Sweden. In MBG Cele, T Luescher \& A Willson Fadiji (eds.) Innovation policy: global debates and local experiences. Cape Town: HSRC Press

Daniels C, Ustyuzhantseva O \& Yao W (2017) Innovation for inclusive development, public policy support and triple helix: perspectives from BRICS. African Journal of Science, Technology, Innovation and Development 9 (5): 513-527

DCDT (Department of Communications and Digital Technologies) (2017) National eGovernment Strategy and Roadmap. Government Gazette No. 41241. DCDT: Pretoria, Republic of South Africa.

DPE (Department of Public Enterprises) (2007) Introduction to the Competitive Supplier Development Programme. DPE: Pretoria, Republic of South Africa, Pretoria. Accessed October 2021, https://www.gov.za/documents/introduction-competitive-supplierdevelopment-programme

Drechsler W \& Karo E (2017) Confucian Public Administration and Innovation Policy: A Conceptual Perspective - Mencius, Max Weber and the Mandate of Heaven. Paper Presented at the 3rd International Conference on Public Policy (ICPP3). 28-30 June. Singapore.

DSI (Department of Science and Innovation) (2019) White Paper on Science, Technology and Innovation. DSI: Pretoria, Republic of South Africa. 
DTICa (Department of Trade and Industry) (n.d.) Trade and Export. DTIC: Pretoria, Republic of South Africa. Accessed February 2021, http://www.thedtic.gov.za/sectors-and-services-2/1-4-2-trade-and-export/

DTICb (Department of Trade and Industry) (n.d.) Special Economic Zone (SEZ). DTIC: Pretoria, Republic of South Africa. Accessed February 2021, http://www.thedtic.gov.za/sectors-andservices-2/industrial-development/special-economic-zones/

DTICc (Department of Trade and Industry) (n.d.) Broad-Based Black Economic Empowerment. DTIC: Pretoria, Republic of South Africa. Accessed February 2021, http://www.thedtic.gov.za/financial-and-non-financial-support/b-bbee/broad-based-blackeconomic-empowerment/

DTICd (Department of Trade and Industry) (n.d.) B-BBEE Procurement and Transformation. DTIC: Pretoria, Republic of South Africa. Accessed February 2021, http://www.thedtic.gov.za/financial-and-non-financial-support/b-bbee/b-bbeeprocurement-transformation-verification/

DTICe (Department of Trade and Industry) (n.d.) Support Programme for Industrial Innovation (SPII). DTIC: Pretoria, Republic of South Africa. Accessed February 2021, http://www.thedtic.gov.za/financial-and-non-financial-support/incentives/supportprogramme-for-industrial-innovation-spii/

DTICf (Department of Trade and Industry) (n.d.) Innovation and Technology Funding instruments. DTIC: Pretoria, Republic of South Africa. Accessed February 2021, http://www.thedtic.gov.za/financial-and-non-financial-support/incentives/innovation-andtechnology-funding-instruments/

Edquist C \& Hommen L (2008) Comparing national systems of innovation in Asia and Europe: theory and comparative framework. In C Edquist \& L Hommen (eds.) Small Country Innovation Systems: Globalization, Change and Policy in Asia and Europe. Cheltenham, UK: Edward Elgar Publishers

Edquist C \& Johnson B (1997) Institutions and organizations in systems of innovation. In C Edquist (ed.) Systems of Innovation. London: Pinter Publishers

Eyewitness News (2016) How Gauteng govt is incubating a business innovation culture in townships. Eyewitness News. November 18. Accessed February 2021, https://ewn.co.za/2016/11/18/ekasilabs-how-gauteng-government-is-instilling-a-culture-ofbusiness-innovation-townships

Foster C \& Heeks R (2015) Policies to support inclusive innovation. Development Informatics Working Paper, 61. Centre for Development Informatics, Institute for Development Policy and Management, SEED, University of Manchester 
Franco JC (2008) Making land rights accessible: Social movements and political-legal innovation in the rural Philippines. The Journal of Development Studies 44 (7): 991-1022

Fressoli M, Arond E, Abrol D, Smith A, Ely A \& Dias R (2014) When Grassroots Innovation Movements Encounter Mainstream Institutions: Implications for Models of Inclusive Innovation. Innovation and Development 4 (2): 277-292

Gupta AK (2006) From sink to source: The Honey Bee Network documents indigenous knowledge and innovations in India. Innovations: Technology, Governance, Globalization 1(3): 49-66

Hart TG, Booyens I \& Sinyolo S (2020) Innovation for development in South Africa: experiences with basic service technologies in distressed municipalities. Forum for Development Studies 47 (1): 23-47

Hood C (1991) A public management for all seasons? Public administration 69(1): 3-19

HSRC (Human Sciences Research Council). (2020). Human Sciences Research Council Strategic Plan 2020-2025. Human Sciences Research Council: Pretoria, Republic of South Africa

IDC (Industrial Development Corporation) (n.d.) Gro-E Youth Scheme. IDC: Johannesburg, Republic of South Africa. Accessed February 2021, https://www.idc.co.za/gro-e-youthscheme/

IR (Information Regulator) (2020) Annual Performance Plan for the 2020/21 Financial Year. IR: Johannesburg, Republic of South Africa

Jacobs PT, Habiyaremye A, Fakudze B, Ramoroka K \& Jonas S (2019) Producing knowledge to raise rural living standards: how universities connect with resource-poor municipalities in South Africa. The European Journal of Development Research 31 (4): 881-901

Kahn MJ (2013) Rhetoric and change in innovation policy: The case of South Africa. Science, Technology and Society 18(2): 189-211

Kankanhalli A, Zuiderwijk A \& Tayi GK (2017) Open innovation in the public sector: A research agenda. Government Information Quarterly 34 (1): 84-89

Kaplan D (2021) Challenges and Constraints for Government Agencies Supporting Firm Level Innovation: Some Reflections from South Africa. In C Daniels, M Dosso, J Amadi-Echendu (eds.) Entrepreneurship, Technology Commercialisation, and Innovation Policy in Africa. Cham, Switzerland: Springer

Karo E \& Kattel R (2015) Economic development and evolving state capacities in Central and Eastern Europe: can "smart specialization" make a difference? Journal of Economic Policy Reform 18(2): 172-187 
Karo E \& Kattel R (2016a) How to organize for innovation: entrepreneurial state and organizational variety. Working Papers in Technology Governance and Economic Dynamics No. 66, The Other Canon Foundation, Tallinn University of Technology

Karo E \& Kattel R (2016b) Innovation and the state: towards an evolutionary theory of policy capacity. Working Papers in Technology Governance and Economic Dynamics No. 72, The Other Canon Foundation, Tallinn University of Technology.

Kraemer-Mbula E, Lorenz E, Takala-Greenish L, Jegede OO, Garba T, Mutambala M \& Esemu $T$ (2019) Are African micro-and small enterprises misunderstood? Unpacking the relationship between work organisation, capability development and innovation. International Journal of Technological Learning, Innovation and Development 11 (1): 1-30

Kruss G (2010) How do universities develop interactive capabilities to promote social innovation and development in South Africa? Globelics 2010 8th International Conference, November 1-3, Kuala Lumpur, Malaysia.

Kruss G \& Lorentzen J (2011) The South African innovation policies: potential and constraint. In JE Cassiolato \& V Vitorino (ed.) BRICS and Development Alternatives: Innovation Systems and Policies. London and New York: Anthem Press.

Kruss G (2012) Reconceptualising engagement: A conceptual framework for analysing university interaction with external social partners. South African Review of Sociology 43 (2): 5-26

Laranja M, Uyarra E \& Flanagan K (2008) Policies for science, technology and innovation: Translating rationales into regional policies in a multi-level setting. Research policy 37(5): 823-835

Lee RG \& Petts J (2013) Adaptive governance for responsible innovation. In R Owen, J Bessant \& M Heintz (ed.). Responsible Innovation: Managing the Responsible Emergence of Science and Innovation in Society. Chichester, UK: John Wiley \& Sons

LaunchLab (n.d.) LaunchLab. Accessed January 2021, https://launchlab.co.za/

Maloa $\mathrm{F}$ (2020) The relationship between the determinants of executive remuneration in South African state-owned enterprises. SA Journal of Human Resource Management 18 (16)

Masilela T (2008) Governance Challenges: Considerations in structuring agencies to support innovation. Faculty Seminar, Faculty of Economics and Finance, September 9, Tshwane University of Technology, Garankuwa

Masutha M \& Rogerson CM (2014) Small enterprise development in South Africa: The role of business incubators. Bulletin of Geography. Socio-economic Series 26 (26): 141-155

Marwala T (2019) Fourth Industrial Revolution: Let's all get to work in a synchronised manner. Daily Maverick. Accessed February 2021, 
https://www.dailymaverick.co.za/article/2019-07-05-fourth-industrial-revolution-lets-allget-to-work-in-a-synchronised-manner/

Mazzucato M (2013) The Entrepreneurial State: Debunking Public vs Private Sector Myth. London: Anthem Press

Mintzberg H (1989) Mintzberg on Management: Inside our strange world of organizations. New York: The Free Press

Mostert L (2020) Playing safely with Personal Information inside a Regulatory Sandbox. Polity. November 03. Accessed February 2021, https://www.polity.org.za/article/playingsafely-with-personal-information-inside-a-regulatory-sandbox-2020-11-03

Mulgan G (2006) The Process of Social Innovation. Innovations: Technology, Governance, Globalization 1 (2): 145-162

Mustapha N, Khan F, Kondlo LO, Takatshana S, Ralphs GP, Whisgary D, Weyers J, Faul KL \& Romanowska E (2017) South African national survey of intellectual property and technology transfer at publicly funded research institutions: inaugural baseline study: 2008-2014. Commissioned by the Department of Science and Technology: Pretoria, Republic of South Africa

National Treasury (2016) National Treasury SCM Instruction No 4A of 2016/2017: Central Supplier Database. National Treasury: Pretoria, Republic of South Africa

National Treasury (2022) Explanatory Memorandum on the Taxation Laws Amendment Bill, 2021. January 25. National Treasury: Pretoria, Republic of South Africa. Accessed February 2022,

http://www.treasury.gov.za/comm_media/press/2022/2021TaxActs/Explanatory\%20Memo radum\%20to\%202021\%20Taxation\%20Laws\%20Amendment\%20Bill-

25\%20\%20January\%202022.pdf

Ndabeni LL, Rogerson CM \& Booyens, I (2016) Innovation and local economic development policy in the global South: New South African perspectives. Local Economy 31 (1-2): 299-311

NICIS (National Integrated Cyberinfrastructure System) (n.d.) https://nicis.ac.za/

OECD (Organisation for Economic Co-operation and Development) (1999) Managing National Innovation Systems. Paris: OECD. Accessed February 2021, https://www.oecdilibrary.org/industry-and-services/managing-national-innovation-systems_9789264189416en

OECD (Organisation for Economic Co-operation and Development) (2007) OECD Reviews of Innovation Policy: South Africa 2007. Paris: OECD. Accessed February 2021, https://www.oecd-ilibrary.org/science-and-technology/oecd-reviews-of-innovation-policysouth-africa-2007_9789264038240-en 
OECD (Organisation for Economic Co-operation and Development) (2010) Public procurement programmes for small firms - SBIR-type programmes. OECD Innovation Policy Platform. Paris: OECD. Accessed February 2021, http://www.oecd.org/innovation/policyplatform/48136807.pdf

OECD (Organisation for Economic Co-operation and Development) (2017) Making Innovation Benefit All: Policies for Inclusive Growth. Paris: OECD

OECD (Organisation for Economic Co-operation and Development). (2019). Embracing Innovation in Government: Global Trends 2019. Paris: OECD

OGP (Open Government Partnership) (2019) Independent Reporting Mechanism (IRM): South Africa End-of-Term Report 2016 - 2018. OGP. Accessed February 2021, https://www.opengovpartnership.org/documents/south-africa-end-of-term-report-20162018/

OpenIX (n.d.) Accessed January 2021, https://www.theinnovationhub.com/innovationprogrammes/openix-5

Owen R, Pansera M, Macnaghten P \& Randles S (2020). Organisational institutionalisation of responsible innovation. Research Policy 50 (1): 104132

Petersen IH \& Kruss G (2019) Promoting alignment between innovation policy and inclusive development in South Africa. Development Southern Africa 36 (3): 351-375

Petersen IH \& Kruss G (2020) Towards a coherent and inclusive NSI: building network alignment through strengthening dynamic interactive capabilities. In MBG Cele, T Luescher \& A Willson Fadiji (ed.) Innovation policy: global debates and local experiences. Cape Town: HSRC Press

Plantinga P \& Adams R (2021) Can open government support innovation for inclusive development? A case study of public innovation policy and management in South Africa. International Journal of Technological Learning, Innovation and Development.

Plantinga P \& Adams R (2020). Rethinking open government as innovation for inclusive development: Open access, data and ICT in South Africa. African Journal of Science, Technology, Innovation and Development 1-9

PMG (Parliamentary Monitoring Group) (2018) SA Research Infrastructure Roadmap \& Integrated Cyber Infrastructure system; South Korea/Japan study tour. National Assembly Committee: Science and Technology. September 05. Accessed February 2021, https://pmg.org.za/committee-meeting/27006/

Razzano G (2021) The Politics of Al and Data: Media and Elections in South Africa. Al \& Data Series 8. Policy Action Network, HSRC. Accessed February 2021, https://policyaction.org.za/ai-data-topical-guide-series 
Reddy P (2011) Global Innovation in Emerging Economies. New York and London: Routledge

Reyneke M (2020) Helping to undo the red tape that ties up social entrepreneurs in bureaucratic knots. Daily Maverick. November 15. Accessed January 2021, https://www.dailymaverick.co.za/article/2020-11-15-helping-to-undo-the-red-tape-thatties-up-social-entrepreneurs-in-bureaucratic-knots/

Rothaermel FT, Agung SD \& Jiang L (2007) University entrepreneurship: a taxonomy of the literature. Industrial and corporate change 16(4): 691-791

SAHRC (South African Human Rights Commission) (2020) Media Advisory: Workshop on "Fourth Industrial Revolution (4IR) and Human Rights: Challenges and Opportunities for National Human Rights Institutions". SAHRC. March 04. Accessed January 2021, https://www.sahrc.org.za/index.php/sahrc-media/news-2/item/2284-media-advisoryworkshop-on-fourth-industrial-revolution-4ir-and-human-rights-challenges-andopportunities-for-national-human-rights-institutions

SAnews (2020) New programme to incubate small businesses in townships and rural areas. SAnews. November 5. Accessed February 2021, https://www.sanews.gov.za/southafrica/new-programme-incubate-small-businesses-townships-and-rural-areas

Scerri M \& Lastres HM (2013). The Role of the State: BRICS National Systems of Innovation. New Delhi: Routledge

Schillo RS \& Robinson RM (2017) Inclusive innovation in developed countries: The who, what, why, and how. Technology Innovation Management Review 7 (7)

Senyolo MP, Long TB, Blok V \& Omta O (2018) How the characteristics of innovations impact their adoption: An exploration of climate-smart agricultural innovations in South Africa. Journal of Cleaner Production 172: 3825-3840

Sibanda M (2021) Nuts \& Bolts: Strengthening Africa's Innovation and Entrepreneurship Ecosystems. Cape Town: Jonathan Ball Publishers.

South Africa Startup Act. 2021. South Africa Startup Act, Position Paper - Update September 2021. Accessed February 2022, https://www.startupact.co.za/progress

The Presidency (2019) Address by President Cyril Ramaphosa to the 1st South African Digital Economy Summit, Gallagher Convention Centre, Johannesburg. July 05. The Presidency:

Pretoria, Republic of South Africa. Accessed January 2022, https://www.thepresidency.gov.za/speeches/address-president-cyril-ramaphosa-1st-southafrican-digital-economy-summit\%2C-gallagher

TIAa (Technology Innovation Agency) (n.d.) TIA. Accessed January 2021, https://www.tia.org.za/ 
TIAb (Technology Innovation Agency) (n.d.) Innovation for Inclusive Development. Accessed January 2021, https://www.tia.org.za/programmes/\#1574887338678-90fc442b-25a9

TIAc (Technology Innovation Agency) (2020) TADF - Call for Expression of Interest. Accessed November 2020, https://www.tia.org.za/blog/2020/10/16/tadf-call-for-expression-ofinterest/

TIH (The Innovation Hub) (n.d.) The Innovation Hub. Accessed January 2021, https://www.theinnovationhub.com/

Tonurist P \& Karo E (2016) State owned enterprises as instruments of innovation policy. Annals of Public and Cooperative Economics 87 (4): 623-648

Tuksnovation (n.d.) Tuksnovation. Accessed January 2021, https://tuksnovation.co.za/

Wu X, Ramesh M \& Howlett M (2015) Policy capacity: A conceptual framework for understanding policy competences and capabilities. Politics and Society 34(3): 165-171 
Table A1: Taxonomy of organisations and routines (adapted and reduced from Karo \& Kattel (2015; 2016a; 2016b))

\begin{tabular}{|c|c|c|c|c|c|}
\hline $\begin{array}{l}\text { Organisation } \\
\text { type }\end{array}$ & $\begin{array}{l}\text { Entrepreneuri } \\
\text { al }\end{array}$ & Machine & Diversified & Professional & Innovative \\
\hline $\begin{array}{l}\text { Organisation } \\
\text { al routines }\end{array}$ & $\begin{array}{l}\text { Simple; } \\
\text { informal; } \\
\text { flexible; little } \\
\text { staff or } \\
\text { middle-level } \\
\text { hierarchy }\end{array}$ & $\begin{array}{l}\text { Centralized } \\
\text { bureaucracy; } \\
\text { formalized; } \\
\text { specialized } \\
\text { work, division } \\
\text { of labour }\end{array}$ & \begin{tabular}{|l} 
'Divisions' \\
loosely \\
coupled \\
together \\
under \\
headquarter \\
\end{tabular} & $\begin{array}{l}\text { Bureaucratic, } \\
\text { decentralized; } \\
\text { pigeonholes' } \\
\text { for } \\
\text { professional } \\
\text { autonomy }\end{array}$ & $\begin{array}{l}\text { Fluid, organic, } \\
\text { selectively } \\
\text { decentralized } \\
\text { 'adhocracy' } \\
\text { (multidisciplinar } \\
\text { y task forces) }\end{array}$ \\
\hline $\begin{array}{l}\text { Strategic } \\
\text { management } \\
\text { routines }\end{array}$ & $\begin{array}{l}\text { Visionary, } \\
\text { flexible, } \\
\text { leadership } \\
\text { based }\end{array}$ & $\begin{array}{l}\text { Planning that } \\
\text { is strategic } \\
\text { programming }\end{array}$ & \begin{tabular}{|l|} 
'Corporate' \\
portfolio \\
strategy and \\
divisions with \\
individual \\
strategies
\end{tabular} & $\begin{array}{l}\text { Stable and } \\
\text { also many } \\
\text { fragmented } \\
\text { strategies by } \\
\text { professional } \\
\text { judgment and } \\
\text { collective } \\
\text { choice } \\
\end{array}$ & $\begin{array}{l}\text { Largely } \\
\text { emergent, } \\
\text { evolving } \\
\text { through a } \\
\text { variety of } \\
\text { bottom-up } \\
\text { processes }\end{array}$ \\
\hline $\begin{array}{l}\text { Personnel } \\
\text { management } \\
\text { routines }\end{array}$ & $\begin{array}{l}\text { Limited } \\
\text { personnel, no } \\
\text { systemic } \\
\text { routines, } \\
\text { needs based } \\
\text { development }\end{array}$ & $\begin{array}{l}\text { Standardized } \\
\text { work and skills } \\
\text { and } \\
\text { recruitment } \\
\text { processes }\end{array}$ & \begin{tabular}{|l|} 
Divided \\
between \\
headquarter \\
and \\
autonomous \\
divisions \\
\end{tabular} & $\begin{array}{l}\text { Dependent on } \\
\text { training to } \\
\text { standardize } \\
\text { the skills of its } \\
\text { professionals }\end{array}$ & $\begin{array}{l}\text { Variety and mix } \\
\text { of skills, } \\
\text { openness to } \\
\text { learning and } \\
\text { experimentatio } \\
\mathrm{n}\end{array}$ \\
\hline $\begin{array}{l}\text { Financial } \\
\text { management } \\
\text { routines }\end{array}$ & $\begin{array}{l}\text { Flexible; } \\
\text { emergent }\end{array}$ & $\begin{array}{l}\text { Efficiency and } \\
\text { process } \\
\text { oriented }\end{array}$ & $\begin{array}{l}\text { Autonomous } \\
\text { divisions, } \\
\text { output } \\
\text { oriented } \\
\end{array}$ & $\begin{array}{l}\text { Mixed; based } \\
\text { on } \\
\text { professional } \\
\text { autonomy }\end{array}$ & $\begin{array}{l}\text { Flexible, not } \\
\text { efficiency } \\
\text { oriented }\end{array}$ \\
\hline $\begin{array}{l}\text { Coordination } \\
\text { routines }\end{array}$ & $\begin{array}{l}\text { Direct } \\
\text { supervision }\end{array}$ & $\begin{array}{l}\text { Standardizatio } \\
\mathrm{n} \text { of work } \\
\text { processes }\end{array}$ & $\begin{array}{l}\text { Standardizatio } \\
\mathrm{n} \text { of outputs }\end{array}$ & $\begin{array}{l}\text { Standardizatio } \\
\mathrm{n} \text { of skills }\end{array}$ & $\begin{array}{l}\text { Mutual } \\
\text { adjustment }\end{array}$ \\
\hline $\begin{array}{l}\text { Capacities } \\
\text { and values }\end{array}$ & $\begin{array}{l}\text { Simple/initial } \\
\text { developments } \\
\text { and changes }\end{array}$ & $\begin{array}{l}\text { Efficiency, } \\
\text { transparency, } \\
\text { accountability }\end{array}$ & $\begin{array}{l}\text { Concentration } \\
\text { of different } \\
\text { focuses }\end{array}$ & $\begin{array}{l}\text { Professional } \\
\text { proficiency }\end{array}$ & $\begin{array}{l}\text { Learning and } \\
\text { complex } \\
\text { innovations }\end{array}$ \\
\hline
\end{tabular}

